\title{
Technology Integration Actions in Mathematics teaching in Brazilian Basic Education: Stimulating STEM disciplines
}

\author{
Acciones de Integración de la Tecnología en la Enseñanza de las \\ Matemáticas de la Educación Básica de Brasil: Estimulando disciplinas \\ STEM
}

\author{
Priscila Cadorin Nicolete \\ Universidade Federal de Santa Catarina, Araranguá, SC, Brasil \\ priscila.cadorin@ufsc.br \\ Simone Meister Sommer Bilessimo \\ Universidade Federal de Santa Catarina, Araranguá, SC, Brasil \\ simone.bilessimo@ufsc.br \\ Marta Adriana da Silva Cristiano \\ Universidade Federal de Santa Catarina, Araranguá, SC, Brasil \\ marta.cristiano@ufsc.br \\ José Pedro Schardosim Simão \\ Universidade Federal de Santa Catarina, Araranguá, SC, Brasil \\ pedro.simao@posgrad.ufsc.br \\ Juarez Bento da Silva \\ Universidade Federal de Santa Catarina, Araranguá, SC, Brasil \\ juarez.silva@ufsc.br
}

\begin{abstract}
Mathematics is a fundamental skill in many aspects of a student's life. Most students everywhere, and in this study in Brazil, sometimes lack motivation to thrive in such subjects. The work presented in this paper aims to contribute to the development of a multiplatform teaching and learning application through the use of Information and Communication Technologies (ICT), in order to encourage the study of mathematics from the first years of basic education. The activities are divided into two areas: training teachers and how to integrate technology in the classroom through the use of mobile learning. The experience was conducted with children from the 5th grade, teaching them fractions and mathematics concepts all as part of a research project called "Technology Integration Proposal in Teaching STEM Disciplines in Public Basic Education", supported by $\mathrm{CNPq}$ - the Brazilian National Council for Scientific and Technological Development, and the project "Use of Remote Experimentation on Mobile Devices for Basic Education in Public Schools" supported by FRIDA (Regional Fund for Digital Innovation in Latin America and the Caribbean). In 2011, this project was selected as one of the most innovative research projects in Brazilian education by the Institute for Development and Educational Innovation (IDIE) of the Organization of Ibero-American States for Education, Science and Culture (OEI) and sponsored by Fundación Telefónica.

Keywords: Educational Technology; Education; Mathematics.
\end{abstract}

\section{Resumen}

A pesar de que la matemática es una habilidad fundamental, la falta de motivación está causando estudiantes brasileños un pobre desempeño en esta disciplina. El trabajo presentado en este documento tiene como objetivo contribuir al desarrollo de 
diversas prácticas de enseñanza y aprendizaje a través del uso de las Tecnologías de la información y la comunicación (TIC), con el fin de motivar el estudio de las matemáticas desde los primeros años de educación básica. Las actividades se dividen en dos áreas: una enfocada en la formación y capacitación de los maestros y la otra centrada en la integración de tecnologías en el aula a través del uso del aprendizaje móvil. La experiencia se realizó con niños de $5^{\circ}$ año, mediante la enseñanza de los conceptos de fracciones. Las actividades son parte del proyecto denominado "Propuesta de integración de la tecnología en la enseñanza de disciplinas STEM en la educación básica pública", con el apoyo del CNPq - Consejo Nacional de Desarrollo Científico y Tecnológico, y el proyecto "Uso de experimentación remota en dispositivos móviles para la educación básica en las escuelas públicas" con el apoyo de FRIDA (Fondo Regional para la Innovación Digital en América Latina y el Caribe). En 2011, este proyecto fue seleccionado como uno de los cuatro proyectos más innovadores en la educación brasileña, en una selección realizada por el Instituto para el Desarrollo y la Innovación Educativa (IDIE) de la Organización de Estados Iberoamericanos para la Educación, Ciencia y Cultura (OEI) y patrocinado por la Fundación Telefónica.

Palabras clave: Tecnología Educacional; Educación; Matemática.

\section{Introduction}

Mathematics is a very important area to all individuals in society and mathematical operations are a big part of the daily human life. However, math is an area with very poor performance among Brazilian students, and these difficulties concern teachers, family and education institutions (EI). This reality can be confirmed in surveys of national and international assessments. Brazil occupies the last positions of the Program for International Student Assessment (PISA) in this area of expertise. In addition, according to the Brazil Exam, a national performance evaluation, a small portion $(11 \%)$ of primary school students of the public school system complete the ninth $\left(9^{\text {th }}\right)$ year knowing that expected for mathematics in years.

Moreover, studies show that these results, in many cases, are linked to the lack of motivation of these students causing, amongst other things, by the way they have been receiving knowledge in classroom, which is sometimes carried out from the outdated procedures and repetitive exercises and training, using superficial and mechanical approaches (Sadovsky, 2007). In this sense, Sadovsky (2007) emphasizes the need to rethink the processes of teaching and learning of mathematics, developing thoughts on what you are learning, showing students the real importance of this area of knowledge in the everyday life.

This research has found that Brazilian students can have difficulties to assimilate with mathematics and other science related subjects and it results in students having poor school performance, studying little and sometimes make them acknowledge the wrong idea about their own ability to perform tasks successfully (Bzuneck, 2001). Bzuneck (2001) also affirms that the lack of motivation of these students is related to different environmental conditions, ranging from the familiar culture and the region where the school is located to the physical structure of the school facilities. This circumstances result in complex interactions between student characteristics and context factors, also including the role of the teacher in the classroom. Thus, the student's engagement in the classroom depends on a set of educational measures and adequate infrastructure to

Technology Integration Actions in Mathematics teaching in Brazilian Basic Education: Stimulating STEM disciplines. Priscila C. Nicolete, Simone M. Sommer, Marta A. da Silva, José P. Schardosim y Juarez B. da Silva.

Página 2 de 22 
promote different teaching strategies to interact with these students, which Brazilian public schools have it precariously, unfortunately.

On the other hand, the impact on social life promoted by Information and Communication Technologies (ICT) represents a unique opportunity for educational development, as these facilitate and provide meaningful learning through technological resources. Corroborating this statement, Butterworth (2002) says that the mathematical abilities are genetically imprinted in our brain and advise to the teaching of mathematics applying models that include the development of intuitive reasoning, the manipulation of materials and activities playfulness (Butterworth, 2002). Therefore, one of the possible ways to try to ease the current situation is to encourage teachers and schools to integrate in math classes more interactivity and exciting ICT technologies, exploring playful digital resources, such as educational games, simulators, videos and images in order to support the teaching and learning of mathematics and other applied sciences.

The lack of motivation and the consequent low yield on applied sciences are directly reflected in careers that these students will follow in the future, or won't. The low number of qualified professionals in STEM subjects (Science, Technology, Engineering and Mathematics) currently represents a major concern worldwide. The existence, the amount and the quality of these professionals in STEM areas are key factors for the economic development of countries and the capacity to innovate, since we live in an increasingly technological world.

However, in developing countries, public EI find it difficult to carry out innovative projects in their classroom, because of the low availability of technological resources. Many schools do not have computer labs or have it precariously. Data from the School Census/INEP 2013 (INEP/MEC, 2013c) show that only 44\% of Brazilian schools have a computer lab, and each laboratory has an average of eight computers for educational use (INEP/MEC, 2013c). In the city of Araranguá, where the research was conducted, the public schools have a rate of one computer per 20.65 students, and considering that the classes have around 35 students, it results in 1.69 per class (INEP/MEC, 2013c). In this scenario, mobile devices such as smartphones and tablets can be a great option to develop projects to integrate ICT into the educational environment considering its low cost, powerful hardware and great expansion in recent years (Unesco, 2014).

Considering these key factors, the work presented in this paper aims to contribute to the development of teaching practices and more attractive and dynamic learning through the use of ICT in order to encourage the study of mathematics in basic education ${ }^{\text {. The }}$ report presented here is about the experience with children of the 5th grade math classes, teaching them concepts of fractions. The methodology focused both on students and on teaching practices, promoting teacher training before the face of educational proposals supported by technology, and a study on their feedback regarding the use of those resources in their professional activities, and only then integrating technology through a lesson plan with activities related to students.

\section{Encouraging Students to Follow Careers in Stem Fields}

Science, Technology, Engineering and Mathematics (STEM) are key areas for the current school education, because they develop skills to provide answers using science

Technology Integration Actions in Mathematics teaching in Brazilian Basic Education: Stimulating STEM disciplines. Priscila C. Nicolete, Simone M. Sommer, Marta A. da Silva, José P. Schardosim y Juarez B. da Silva.

Página 3 de 22 
and technology in today's society. The qualifications in these areas play a very important role in a wide range of contemporary occupations, because we live in a highly technological and competitive world, being innovation, research and technological development a bottom line for developing countries.

However, as the demand for skilled labor in scientific and technological areas increases, the number of young people interested in entering these areas drops (Gramani \& Scrich, 2013), and the shortage of these professionals is a concern in many countries, both developed and developing countries. In Brazil, only $21.6 \%$ out of 10,000 inhabitants enroll in these areas, $9.0 \%$ enter and only $2.9 \%$ conclude their studies (INEP/MEC, 2013b). Abiding these figures, by 2020 Brazil will be in deficit of 408,000 qualified IT professionals, according to a survey of NISB / Softex Observatory (Softex, 2013).

This scenario is a reflection of poor performance of students in public primary education. According to data from INEP / MEC taken from the results of Prova Brasil, a national exam for primary and secondary students, they learned that only $35 \%$ of students in the 5th year in public schools had problem-solving skills and in elementary school II (6 to 9 years) this percentage is even worse, representing only $11 \%$ of students, i.e., almost one in ten students. (INEP/MEC, 2013a).

In addition, Brazil remains in one of the last positions in PISA ranking. Brazil obtained the 58th position and reached 391 points for an average of 494 among members of the OECD in mathematics. The survey also shows the score which indicates that 2 out of 3 15 year-old Brazilian students cannot interpret situations that require only direct deductions from information given, are not able to understand percentages, fractions or graphics (OECD, 2013). The data presented corroborate McPherson and Anid(2014), who claim that the quality in the teaching of STEM areas for students in basic education is crucial to academic success and preparing these students for the job market of the 21st century (McPherson \& Anid, 2014).

Another major issue in Brazilian education is the elitism in higher education, despite the small number of students enrolled in primary education in private schools, only $16.46 \%$ of the population, these represent the majority in public universities (INEP/MEC, 2013c). In 2015, 56.54\% of the students accepted for the Federal University of Santa Catarina (UFSC) come from private schools, while students from public schools account $43.46 \%$ (Coperve, 2015).

This inequality in the access to higher education related to young people from public schools is caused by the lack of attention given the quality of public basic education, lack of investment in education, educational inequalities among social classes and the selection process that hamper access to this level of education. Furthermore, the interest of young people on issues related to science and mathematics is dwindling, and many studies claim that there is a link between the attitude of the youth towards science and the way the contents are taught (Gallant, 2010)(de Lima et al., 2014)(Dziabenko \& García-Zubía, 2013).

Mathematics is present in almost every moment of our lives and we have contact with it since the early age. However, when the subject is taken to the classroom, with its

Technology Integration Actions in Mathematics teaching in Brazilian Basic Education: Stimulating STEM disciplines. Priscila C. Nicolete, Simone M. Sommer, Marta A. da Silva, José P. Schardosim y Juarez B. da Silva.

Página 4 de 22 
formulas and purely theoretical concepts, it becomes a major problem in academic life turning into a great villain for students. The difficulties students have to assimilate with mathematics has as a direct consequence of the lack of engagement in other subjects involving calculations, such as physics and chemistry, that are essential for careers in science and technology areas.

One consequence of this funding between Higher Education and Basic Education is the continuing student failure, especially in the areas of Mathematics, Natural and Exact Sciences with a consequent increase in evasion. A typical case are the subjects of Physics and Calculus I, in the first year of engineering on Federal University of Santa Catarina (UFSC) at Araranguá, with an average of disapproval of 53.2\% and $65.5 \%$ respectively in 2012 (CAGR, 2013).

The teaching of scientific-technological and engineering areas starts in Basic Education and cannot be dissociated from it. The low number of professionals in these areas and the accumulated deficit professional is directly proportional to the gentrification of the ES in Brazil, his detachment and the consequent lack of dialogue with Basic Education, which makes the freshmen see engineering as a "black box" when there are faced with concepts, methods and techniques fully alien to their expectations.

In this scenario, it is understood that the teaching of scientific-technological and engineering areas starts in Basic Education and cannot be dissociated from this. The low number of professionals in these areas and the accumulated deficit of professionals is directly proportional to the ES of gentrification in Brazil, its distance and the consequent lack of dialogue with the Basic Education, which causes the freshmen see engineering as a "black box" when there are faced with concepts, methods and techniques totally alien to their expectations.

Thus, it is essential that basic education be rethought in terms of country. It is necessary to combat high dropout in primary education, avoiding the retention of students in the transaction for the high school. And that goes for the recovery and upgrading of teachers for curricular issues and better infrastructure. Regarding curriculum issues is necessary to develop and apply methodologies of teaching and learning to take ownership of the resources made available by ICT from the initial series, in order, exploit them as auxiliary resources to support the construction of concepts and motivation of these students (Tajra, 2011).

We live today in a society that is undergoing constant change with the evolution of science and technology - and now the individual has contact, at an earlier age with the technological resources. Instruments such as mobile computers and devices are part of the current culture and everyday reality. Therefore, technology takes on an important function in terms of educational support in the education system.

In this new reality it is necessary to search for new teaching methodologies, and educators need differentiated and consistent educational tools with the reality in which students are entered. The school has to be closer to his time, searching through ICT means to harness the full potential of each student - improving in this way, the act of teaching and learning allying technological advances.

Technology Integration Actions in Mathematics teaching in Brazilian Basic Education: Stimulating STEM disciplines. Priscila C. Nicolete, Simone M. Sommer, Marta A. da Silva, José P. Schardosim y Juarez B. da Silva.

Página 5 de 22 
Using ICT can transform the dynamics in math classes, making the lectures integrated to practice and providing resources that help in securing content and approach of theory with everyday life. ICT can be in a mathematical laboratory that experience, develop intuition, conjecture, prove, show and "see the mathematical situations" in a practical way. For this reason, ICT has become a valuable teaching tool, offering great possibilities to education. It can produce significant changes in teaching methods and the way in which students can access and interact with the mathematical knowledge (Hofmann, 2006).

Among the resources of ICT, mobile devices have been shown to be very promising. From the great expansion of mobile technologies, mobile learning was bet in the current environment for teaching and learning in various subjects.

\section{Mobile Learning in mathematics teaching}

One of the ways to innovate in the educational environment through ICT is the use of mobile devices, this mode known as Mobile Learning. The term Mobile Learning or mLearning is a concept associated with the use of mobile technology in education and can be considered as the intersection of "mobile computing" and "e-Learning" to produce an educational experience anywhere and anytime (Hofmann, 2006), in a broad context of resource utilization (Welsh, Wanberg, Brown, \& Simmering, 2003).

Mobile learning has the potential to become an integral part of teaching and learning processes, it is increasingly common for students to have and use mobile technologies. These devices are digital devices, with powerful and affordable hardware, easily portable, easy interaction and access to the Internet, running a large number of actions, including multimedia (Unesco, 2014). These devices are new doors for teaching, learning, collaboration, and continuous productivity stimulated by the Internet.

The m-learning is among the new trends to transform teaching and learning processes (Johnson, Adams Becker, Estrada, \& Freeman, 2014) (Johnson, Adams Becker, Estrada, \& Freeman, 2015), (Unesco, 2014). They allow you to learn anytime and anywhere, making the formal and informal learning to approach, building new dynamic and stimulating environments for students (INEP/MEC, 2013a). Being constantly connected, ease of communication and content sharing, and easy location information makes these devices can perform different tasks related to learning, exploring vast majority of resources available on the Web 2.0.

In this regard, Unesco (2015) points out that the use of mobile technologies leverage new educational opportunities and their use is also justified by the increasing use of such devices by students and teachers, making teaching and learning simple and ubiquitous.

However, it is noteworthy that the popularization and advantages of mobile technologies do not rule devices such as desktop and laptop computers. Currently we see a tendency to use blended learning scenarios - Blended Learning - combining different forms of learning, integrating various ways of access to content (Goh, 2009). Some learning content, for example, can be best used in devices with larger screens,

Technology Integration Actions in Mathematics teaching in Brazilian Basic Education: Stimulating STEM disciplines. Priscila C. Nicolete, Simone M. Sommer, Marta A. da Silva, José P. Schardosim y Juarez B. da Silva.

Página 6 de 22 
such as desktops and smart boards, which offer better opportunities to show and create larger pieces of content (Goh, 2009). In the process of integration of ICT in schools it is important to have the technologies only as interfaces mediating teaching, not putting them at the center, but as mediators of the whole process. Since teachers bring different ways of approach to the classroom, collaborate for a greater number of students is reached properly.

Nevertheless, in places where the shortage of technological resources prevent teachers to innovate in their teaching methodologies, mobile devices offer new exciting ways to improve education, enabling digital inclusion in the poorest and remote places, since studies They show that mobile technology is the most pervasive technology and quickly adopted the story (Unesco, 2014) (Unesco, 2015) and are very common, even in areas where schools, books and computers are rare (Unesco, 2014).

According to Batista, Behar and Passerino (2010), mobile applications used for teaching and learning mathematics favor interactivity, learning in real contexts and collaborative practices. Furthermore, Barbosa Neto and Fonseca (2013) believe that the use of mobile devices and games increase students' interest in math classes. In this sense, Pereira and Rodrigues (2013) present a series of government initiatives for the use of mobile devices in mathematics and other classes. Malaysia, India and China, among others, have encouraged the use of mobile devices in education. However, this process of integrating m-learning requires efforts to train teachers, in order to make them able to use this technology in class.

\section{TPACK and Teacher Training}

Considering the changes generated in technological integration, whether for teachers or students, the school needs to adapt to the pedagogical models that transcend traditional classes. The search for more dynamic and modern school has a wide variety of currently available technological resources, and need to use forms to apply them in the classroom in order to streamline the process of teaching and learning constantly. For Catapan and Fialho (1999) the current demand of education requires infrastructure plan relating pedagogy and technology, with a multidimensional look of the educational process (Catapan \& Fialho, 1999).

The interactivity of the internet and plenty of technological resources available today for education makes the mobile learning or blended learning systematically applied in the educational field. That is exactly why new methods, devices and techniques should be constantly sought, in order to keep the balance about the dichotomy pedagogy and technology, applying effective lessons using VLEs, remote labs or simulators, for example. However, so many possibilities require adequate teacher. Mishra and Koehler also mention that one should not only design and plan new modes of teaching and learning, but also seek new positions and attitudes of teachers, since for the author teachers will have to do more than just learn in order to use the tools currently available (Mishra \& Koehler, 2006).

In this perspective, which goes beyond the handling of technology in terms of a more effective submersion in specific knowledge, it is sought to teach with the support of

Technology Integration Actions in Mathematics teaching in Brazilian Basic Education: Stimulating STEM disciplines. Priscila C. Nicolete, Simone M. Sommer, Marta A. da Silva, José P. Schardosim y Juarez B. da Silva. 
technological resources. It is necessary to focus on the teacher and the methodology and teaching, developing their cognitive skills, and embracing the different types of knowledge necessary for using these new features effectively.

In order to understand the interrelationships between science, technology and pedagogy, it was used the TPACK (Technological Pedagogical Content Knowledge) Framework, released by the studies of Punya Mishra and Matthew J. Koehler, both at the State University of Michigan in the United States States (Koehler \& Mishra, 2009; Mishra \& Koehler, 2006).

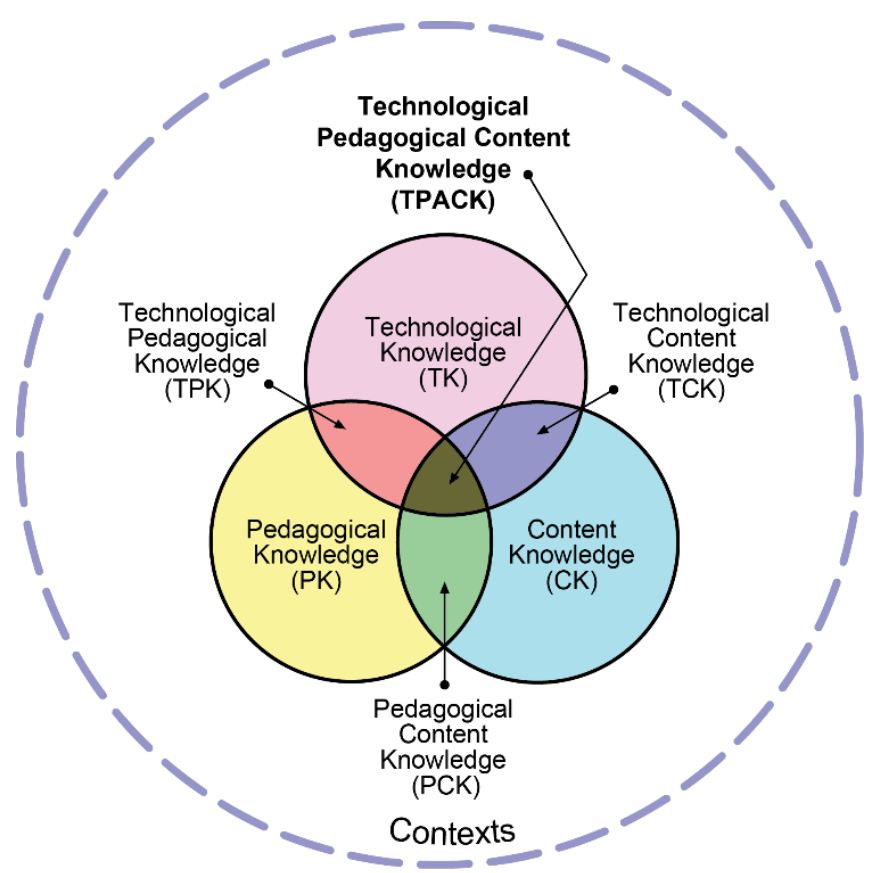

Figure 1. TPACK. Reproduced by permission of the publisher, (C) 2012 by tpack.org

The TPACK framework (Technological Pedagogical Content Knowledge approach) provides a conceptual theoretical model for integrating technology in the classroom that seeks to understand the interrelationships between science, technology and pedagogy (Mishra \& Koehler, 2006). The framework was developed by Shulman (1986) and adapted by Punya Mishra and Matthew J. Koehler, University of the State of Michigan in the United States (Koehler \& Mishra, 2009; Mishra \& Koehler, 2006). This framework observes, describes and considers the three sources of knowledge:

- Content Knowledge (CK): this knowledge is linked to the content to be taught according to each subject and includes the knowledge of the practices and approaches that result in the development of knowledge of a particular subject.

- Pedagogical Knowledge (PK): this knowledge is linked to the strategies and ways of teaching the contents to be worked on more efficiently class. If a teacher has a profound disciplinary knowledge can understand how students construct their own knowledge and develop skills that predisposes positively to learning.

- Technological Knowledge (TK): this knowledge is linked with ICT tools that teachers will select to work in class with their students. These tools are always being updated which can be boring for the teacher. No doubt there are ways of

Technology Integration Actions in Mathematics teaching in Brazilian Basic Education: Stimulating STEM disciplines. Priscila C. Nicolete, Simone M. Sommer, Marta A. da Silva, José P. Schardosim y Juarez B. da Silva. 
thinking and working with technology that can be applied to any technological tool.

Interconnection of this knowledge is to develop practices that address teaching mediated efficiently and effectively technologies. This framework of the combination of CK, PK and TK specifically, and from the intersection of these, proposed evaluation by the association of Educational Knowledge Content (PCK), Technological Knowledge Content (TCK) and Educational Technology Knowledge (TPK). After the first interaction of knowledge, it is still possible a new intersection and reach the Educational Technological Knowledge Content (TPCK) which is considered the ideal knowledge for teachers to integrate technology into their teaching practice(Mishra \& Koehler, 2006).

\section{Methodology}

Five strategic lines shaped the methodological activities related to the project: (1) activities related to teachers; (2) activities related to students; (3) activities related to school infrastructure; (4) provision of services to be used in developing the project by $\mathrm{RExLab}^{\mathrm{II}}$ and (5) evaluation strategies. Whereas for each of these lines include the phases of preparation, implementation and operation, featuring the name "3C": context, conduct and conclude (Avison, 1991). This paper will be presented only the strategic lines 1, 2 and 4 only by setting the focus of the applicability of the project. Table 1 shows the phases of preparation, implementation and operation of these strategies.

In order to stimulate the teachers' ability to interrelate the different knowledge set in TPACK methodology, the methodology described here has two axes: a training one and an integration technology one. Thus, in activities related to teachers (strategic line 1) was sought in the preparation phase to identify the factors that influence the degree to which teachers integrate technology into their lessons.

These technology-influencing factors about the practice teacher were obtained through questionnaires for data collection, categorization of these data according to the TPACK and data analysis. With the results it was elaborated a training for all teachers involved in the project.

The questionnaire was answered by 147 teachers of the School of Basic Education Otávio Manoel Anastácio with, sets the stage of execution, as the data and information obtained at this stage are crucial for defining the teacher training activities. The execution phase includes workshops, short courses and lectures for the teachers. The strategies related to students (strategic line 2) consist of training on the use of Moodle, and the use of tablets, purchased with the project resources and used in practical activities.

The conclusion phase consists of the administration of the questionnaire and obtaining identification data. In the operation phase, are held activities on the tablets in classes taught by subject teacher. During these lessons the teacher can count on the support of members of RExLab project participants, supporting the preparation of lessons according to the TPACK framework.

Technology Integration Actions in Mathematics teaching in Brazilian Basic Education: Stimulating STEM disciplines. Priscila C. Nicolete, Simone M. Sommer, Marta A. da Silva, José P. Schardosim y Juarez B. da Silva.

Página 9 de 22 
The preparation phase of provision of services (strategic line 4) is to give the team executing awareness of the project, context analysis and study the educational object to be worked with, considering the requirements, the design specifications, software technologies and hardware involved in the project to ensure that its implementation is relevant and reach the established objective.

In the realization phase, the team performs the installation and configuration of the necessary technologies. Being all computer software is open source, the team documents all the steps and procedures, drafting manuals and guides related to installation and setup procedures. In this phase are also made connection tests and computer security of the implemented system.

In the operation phase, we provided teachers with continuous educational content to use in classrooms, because they need to be continuously adjusted to the Virtual Learning Environment format. This phase aimed to provide relevant information to support the technological and pedagogical model. Also, includes the presentation and implementation of the environment by the academic community.

Table 1

Strategic lines and macroscopic steps " $3 C^{\prime \prime}$

\begin{tabular}{|c|l|l|l|}
\hline & \multicolumn{1}{|c|}{ Preparation } & \multicolumn{1}{c|}{ Realization } & \multicolumn{1}{c|}{ Operation } \\
\hline $\mathbf{1}$ & $\begin{array}{l}\text { Identify technology influence } \\
\text { factors in teaching practice }\end{array}$ & $\begin{array}{l}\text { Apply questionnaire to the } \\
\text { participant teachers }\end{array}$ & $\begin{array}{l}\text { Develop workshops, } \\
\text { short courses and } \\
\text { lectures for teachers }\end{array}$ \\
\hline $\mathbf{2}$ & Realize professional trend & $\begin{array}{l}\text { Apply questionnaire; } \\
\text { Obtain identification data; } \\
\text { Enable the use of tablets. }\end{array}$ & $\begin{array}{l}\text { Perform classes with } \\
\text { tablets. }\end{array}$ \\
\hline Specifications; & $\begin{array}{l}\text { Install and Configure } \\
\text { technologies. }\end{array}$ & $\begin{array}{l}\text { Support the } \\
\text { technological and } \\
\text { pedagogical aspects }\end{array}$ \\
\hline
\end{tabular}

Finally, to receive feedback from the students who participated in the project and validated the work, we designed a questionnaire that evaluates the technological profile of the students as well as their perception of the use of technology in the classroom. The questionnaire was designed with 15 questions, and the $6 / 1$ set for lifting the technological profile of each student and the following questions, 7-15, elaborated with five options each, with varying among awful, bad, indifferent, good and great, as shown Figure 2 in order to obtain an adequate feedback of classes taught with support from technology. 


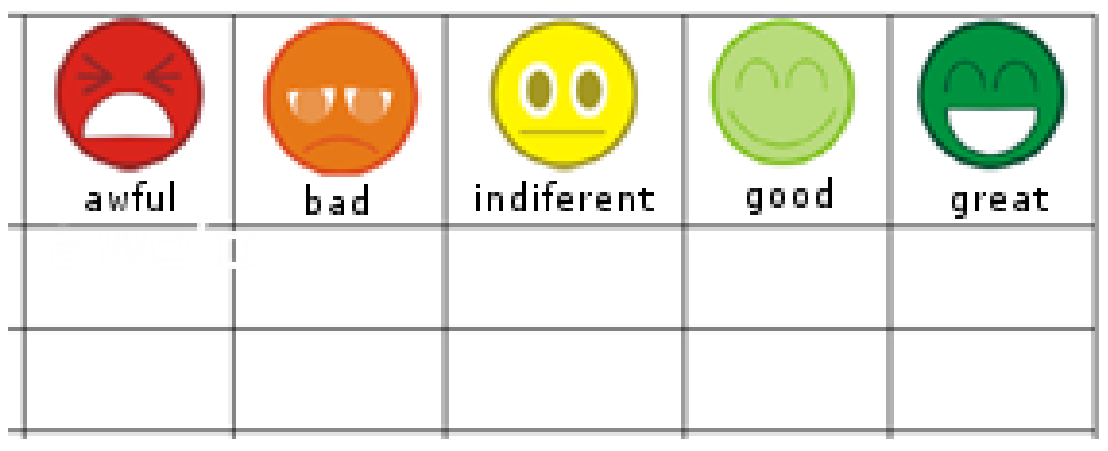

Figure 2. Student perceptions questionnaire

Similarly, to obtain feedback with the teachers, an open interview in which each one could express their experience took place, highlighting advantages and disadvantages regarding the use of ICT in their classes.

Two questionnaires were applied during a training action to all 25 teachers from EOMA. The first had questions about the teachers' profile and the second teacher perception of the integration of technology into their lessons. The first questionnaire consists of twenty (20) questions, seeks to characterize the profile of the teachers participating in the project. The second questionnaire contains 36 items and was adapted from the study "Survey of Teachers Knowledge of Teaching and Technology", about the perception of teachers on teaching and technology. Upon receipt of the responses, it was made the categorization of the questionnaire prepared for teachers according to the domain TPACK.

For teachers to express their level of acceptance or rejection, the questions were arranged according to the Likert scale. Answers to the 36 questions in the questionnaire were categorized, and the data obtained in the questionnaire were grouped according to the seven subscales defined in TPACK framework.

\section{Results}

At the end of the activities described in this article, two aspects that considered crucial for the integration of ICT in math classes are presented the results obtained: the teaching profile according to the TPACK framework and the feedback from the production of traditional math classes, basic education, supported by mobile technological devices.

\section{Faculty Profile - TPACK}

The questionnaire on the teacher profile applied at the Escola de Educação Báscia Otávio Manoel Anástacio presented data on the distribution of teachers according to age. Table 2 shows the results, which most teachers are in the range of 36 to 50 years, distributed as follows:

Technology Integration Actions in Mathematics teaching in Brazilian Basic Education: Stimulating STEM disciplines. Priscila C. Nicolete, Simone M. Sommer, Marta A. da Silva, José P. Schardosim y Juarez B. da Silva. 
Table 2

Age range of teachers surveyed

\begin{tabular}{|c|c|c|c|c|c|c|}
\hline $\mathbf{1 8 - 3 0}$ & $\mathbf{3 1 - 3 5}$ & $\mathbf{3 6 - 4 0}$ & $\mathbf{4 1 - 4 5}$ & $\mathbf{4 6 - 5 0}$ & $\mathbf{5 1 - 5 5}$ & $\mathbf{5 6 - 8 0}$ \\
\hline $5 \%$ & $10 \%$ & $30 \%$ & $20 \%$ & $20 \%$ & $5 \%$ & $10 \%$ \\
\hline
\end{tabular}

Another important data obtained from the teachers is the distribution by degree. It was observed that all teachers are graduates and most of them (90\%) have at least one specialization; however, none of them had a master's or doctor's degree. When asked about the reasons, the teachers were unanimous in pointing out the lack of stimuli. One of these reasons was that most Brazilian teachers work in a very significant workload reaching 40 and 60 hours per week. The other was the salary value, where the benefit for a degree in a strict sense, is but a negligible value, giving no motivation for these professionals to seek for the greatest experiences.

Another important factor, which gives us an overview of the project participant school teachers is that $85 \%$ of school teachers have more than 10 years of teaching experience, and only $5 \%$ of teachers have 6 to 10 years of teaching experience.

The score calculated for this school TPACK was 3.25 (standard deviation [SD] $=0.54$ ), in a range of 1 to 5. The highest average subscale score was the PK - Pedagogical Knowledge, averaging $390, \mathrm{SD}=0.24$, while the lowest average was in the subscales TK - Technological Knowledge, averaging 2.65, SD = 0.57 and TCK - Technological Knowledge Content, averaging 2.62, $\mathrm{SD}=1.34$, clearly demonstrating that the technology integration in the classroom still needs to be worked quite, according to Table 4.

Table 3 shows that teachers perceive a very clear way his deficiencies the technological knowledge. However, when it is the first intersection of knowledge we can see the trend towards highly visible neutrality in subscale TPK - Educational Technology Awareness, the answers given by teachers show that uncertainty about knowledge of technologies and Their potential in teaching and learning and how teaching can change as a result of your application.

Technology Integration Actions in Mathematics teaching in Brazilian Basic Education: Stimulating STEM disciplines. Priscila C. Nicolete, Simone M. Sommer, Marta A. da Silva, José P. Schardosim y Juarez B. da Silva. 
Table 3

TPACK Scores

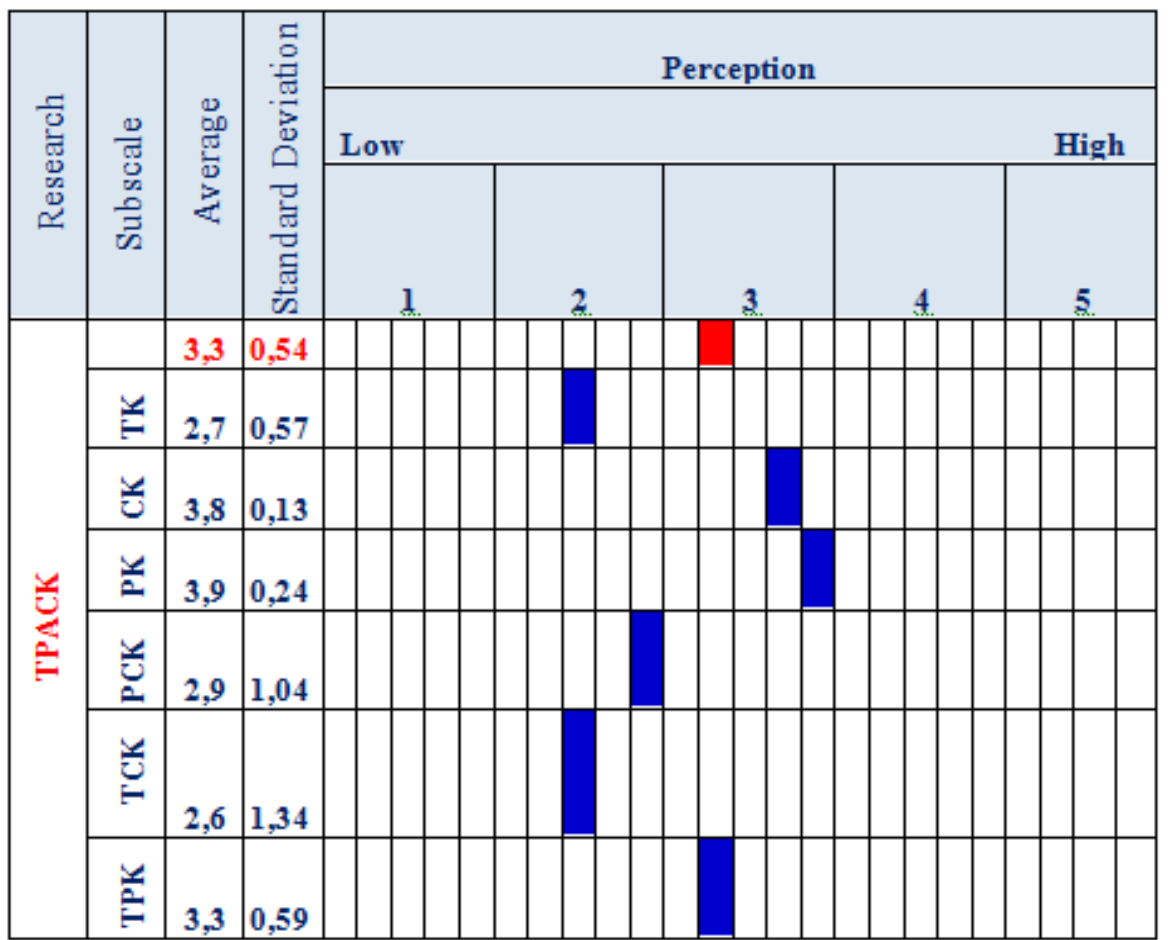

\section{Technology integration in mathematic classes}

The pilot project is being conducted in four Brazilian public schools: Escola de Educação Básica Professora Maria Garcia Pessi (EMGP); Escola Municipal Otávio Manuel Anastácio (EOMA); Escola Municipal do Jardim das Avenidas (EMJA); Escola de Educação Básica Apolônio Ireno Cardoso (EBAIC).

In the Escola Municipal de Educação Básica Otávio Manuel Anastácio (EOMA) are being developed courses of Mathematics and Sciences with 363 students divided into 20 classes. From this point we report the activities in mathematics, in the 5th year of elementary school, with a total of 41 students enrolled, divided into two classes, taught by the teachers Edinéia and Zeni.

These students had at their disposal the material used in class in digital format, could perform related activities in the virtual learning environment (Moodle), and could perform practices with use of educational games, accessed by smartphones, tablets or computers. Teachers participating in the project, together with RExLab team, developed the resources that were made available. During the development of the project were used online learning materials, illustrative material such as comic books and videos, the VLE (Moodle) resources, and digital educational games, as shown in Figure 3.

Technology Integration Actions in Mathematics teaching in Brazilian Basic Education: Stimulating STEM disciplines. Priscila C. Nicolete, Simone M. Sommer, Marta A. da Silva, José P. Schardosim y Juarez B. da Silva. 


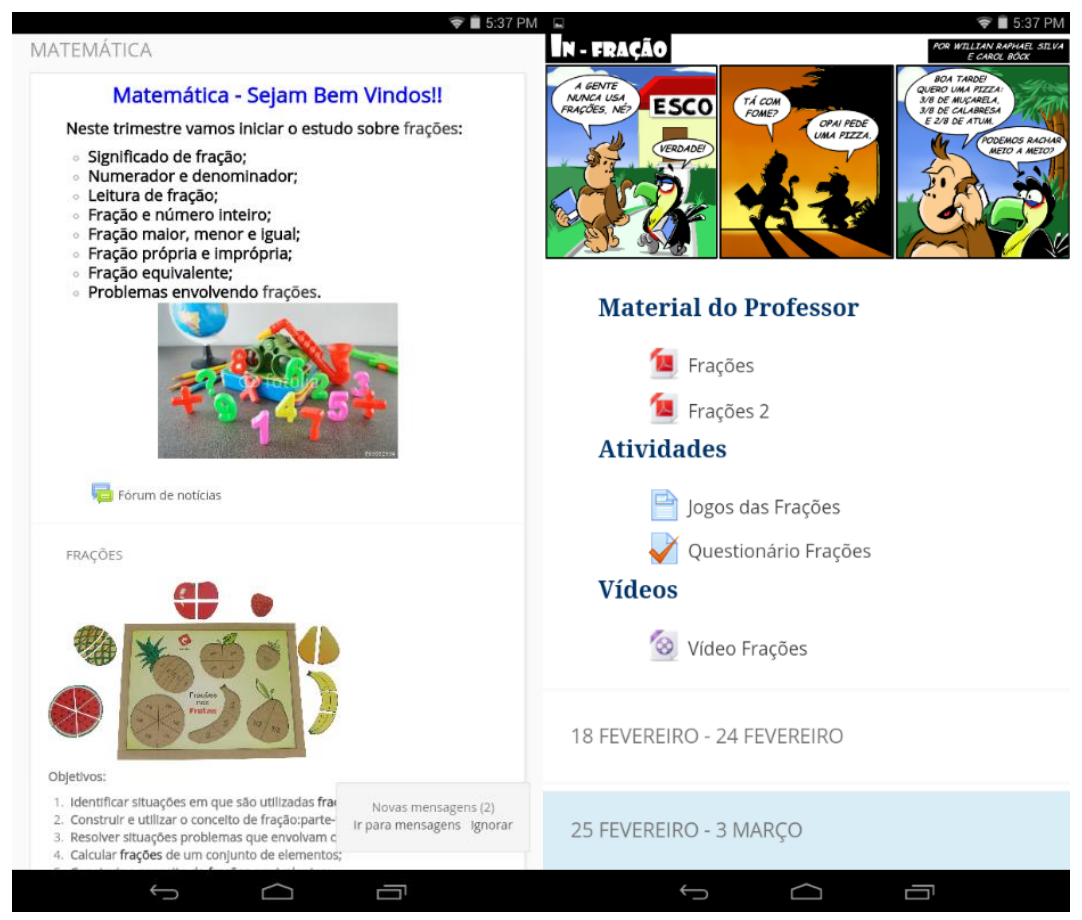

Figure 3. Material on Moodle for student use. Source: Moodle (http://rexmobile.ufsc.br/moodle/)

The contents taught were operations with fractions, such as: part-whole, solve problem situations involving the concept of fraction, calculating fractions of a set of elements, build the concept of fractions equivalents, compare fractions with denominators same or different and recognize major fraction and less than the whole. Figure 4 shows part of the video feature used in class.

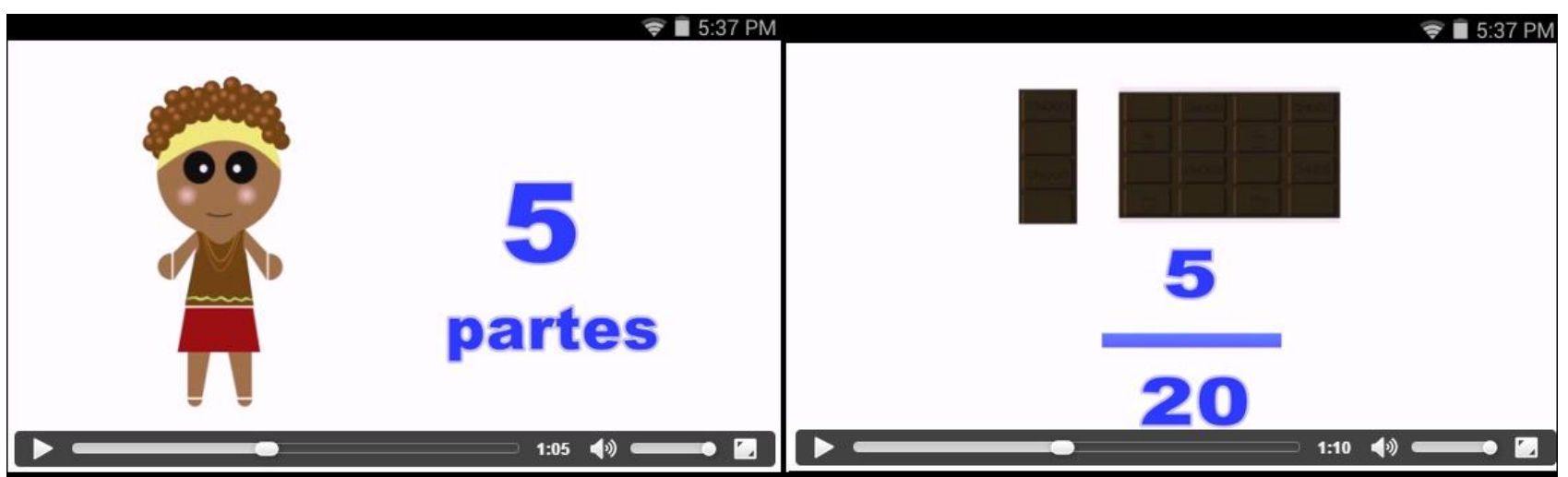

Figure 4. Video about fractions used in mathematics classes. Source:

https://www.youtube.com/watch?v=ai-nnkEOX38

The teachers also used some games as a playful way of teaching fractions. Among the games chosen are the games "Simply Fractions" and "Fracciones". The game "Simply Fractions" was developed for Android platform by Simply LearningAid and it is freely available in store Google Play Store. It is designed to help elementary school students understand the concepts of fractions illustrative and entertaining exercises.

Technology Integration Actions in Mathematics teaching in Brazilian Basic Education: Stimulating STEM disciplines. Priscila C. Nicolete, Simone M. Sommer, Marta A. da Silva, José P. Schardosim y Juarez B. da Silva. 
The second game used by the children was the "Fracciones" (Figure 5), developed by Spanish Vedoque team. "Fracciones" is an educational game for pedagogical support for math, with a specific focus on learning about fractions operations. It is a dynamic game with 2D animations, developed in Swish Max, an API that uses Adobe Flash technology to create cross-platform presentations and can be exported as Flash files, executable (.exe) or HTML.

The Vedoque is a website (http://www.vedoque.com/) containing educational resources with which RExLab team has collaborated since 2008. Due to the partnership with Vedoque team, the game, that originally is available in Spanish, was translated into Portuguese by Rexlab team. However, the game Simply Fractions was not used completely, because it is a game developed in English.
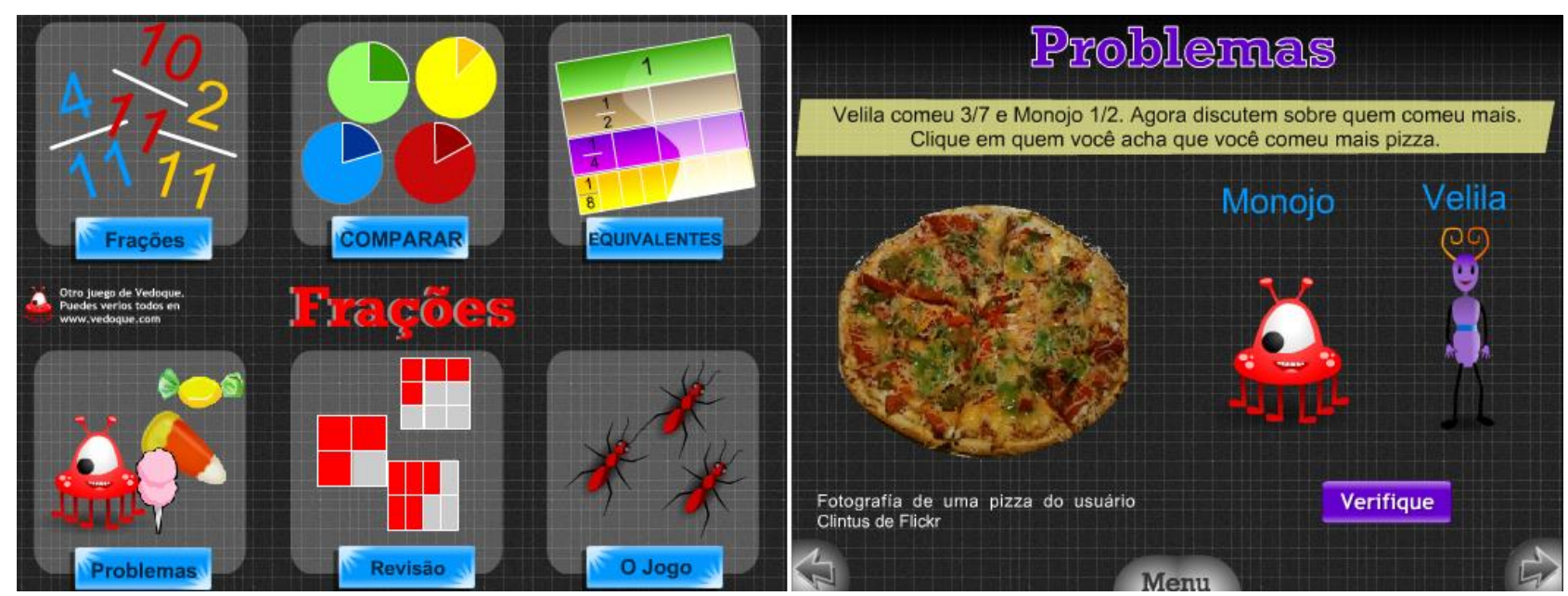

Figure 5. Game "Fracciones". Source: www.vedoque.com

Since the game "Fracciones" was developed with Flash technology, that was discontinued for use in Android platform, its use by students was held in desktops. In this class, the students were taken to the computer lab of the Federal University of Santa Catarina (UFSC) (Figure 6), since the school's computer lab had only 4 computers that could be used by students.

Technology Integration Actions in Mathematics teaching in Brazilian Basic Education: Stimulating STEM disciplines. Priscila C. Nicolete, Simone M. Sommer, Marta A. da Silva, José P. Schardosim y Juarez B. da Silva. 


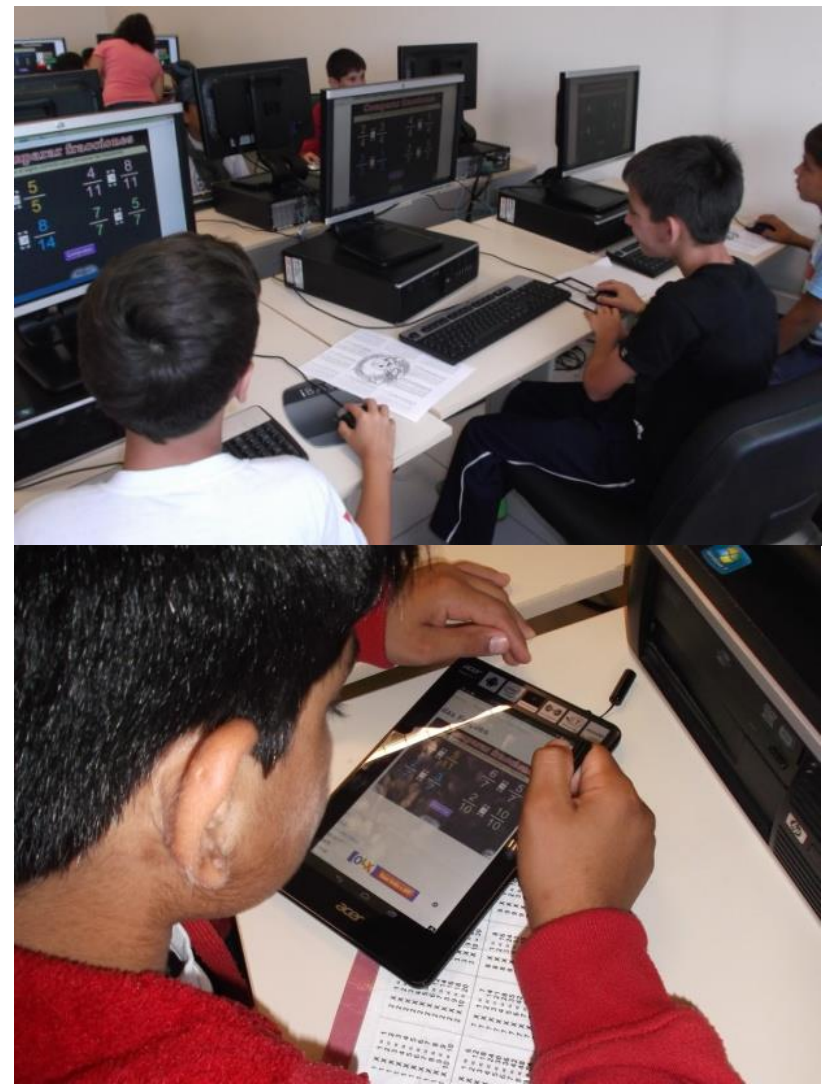

Figure 6. Students at the university computer lab

After the activities were developed, it was applied the questionnaires of technological profile and student perception. The questionnaires presented questions using Likert scale in order to present the level of student satisfaction with the actions taken.

In the technological profile it is evident the lack of students with regard to everyday use of tools like computer and the internet, both in school and outside it, with $32.9 \%$ of students stating that they do not have or do not. It has access to computing devices, and $43.2 \%$ do not use or do not have Internet access. Another interesting aspect is that among those who already use computers or other devices, $80 \%$ claim to have learned to use these technologies with members of their own family, and only $3.7 \%$ said she learned in school about the use of computers. This number is even more worrying as compared to learning to use the Internet, in which $4 \%$ claim to have learned to access it in cyber cafes against any claim about learning about it in school.

As the perception of students with use of technological resources in math classes, Table 4 shows very clearly the acceptance of the same with classes held. In all nine (9) questions, students present a positive trend to use the resources offered with a result above 3.5 points, which reinforces student wish to have classes that are more current and according to what is expected an education-focused student.

Technology Integration Actions in Mathematics teaching in Brazilian Basic Education: Stimulating STEM disciplines. Priscila C. Nicolete, Simone M. Sommer, Marta A. da Silva, José P. Schardosim y Juarez B. da Silva. 
Table 4

Scores of using technology acceptance perception in elementary school

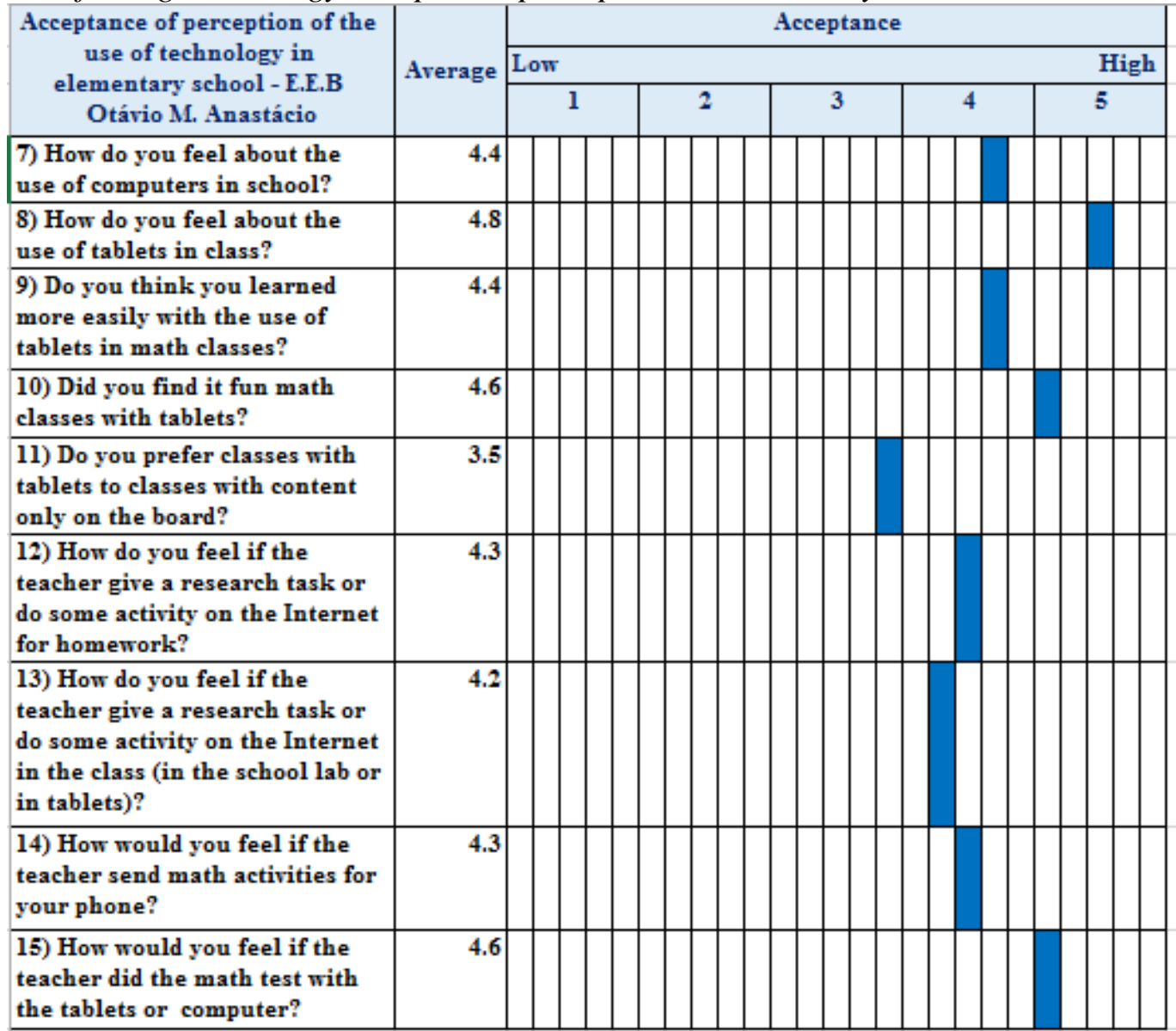

According to Table 4, in question 8 , when directly questioning the student about the specific class using the tablets, with a value far right is expressed, representing the acceptance of the methodology applied in math class. However, it also highlighted the issue eleven (11) with the lowest displayed value, as can be seen in Figure 7. At this point students were asked about the preference between the strategies used in the classroom, the value of 3.5 indicates that it is not a matter of preference for the technology but to explore a wide range of methodologies. So turns the Blended Learning methodology, which proposes that develops classroom lecture with frame and pen, and electronic devices such as computers and tablets, exploring digital learning objects, balanced way among the traditional and the new.

Technology Integration Actions in Mathematics teaching in Brazilian Basic Education: Stimulating STEM disciplines. Priscila C. Nicolete, Simone M. Sommer, Marta A. da Silva, José P. Schardosim y Juarez B. da Silva. 


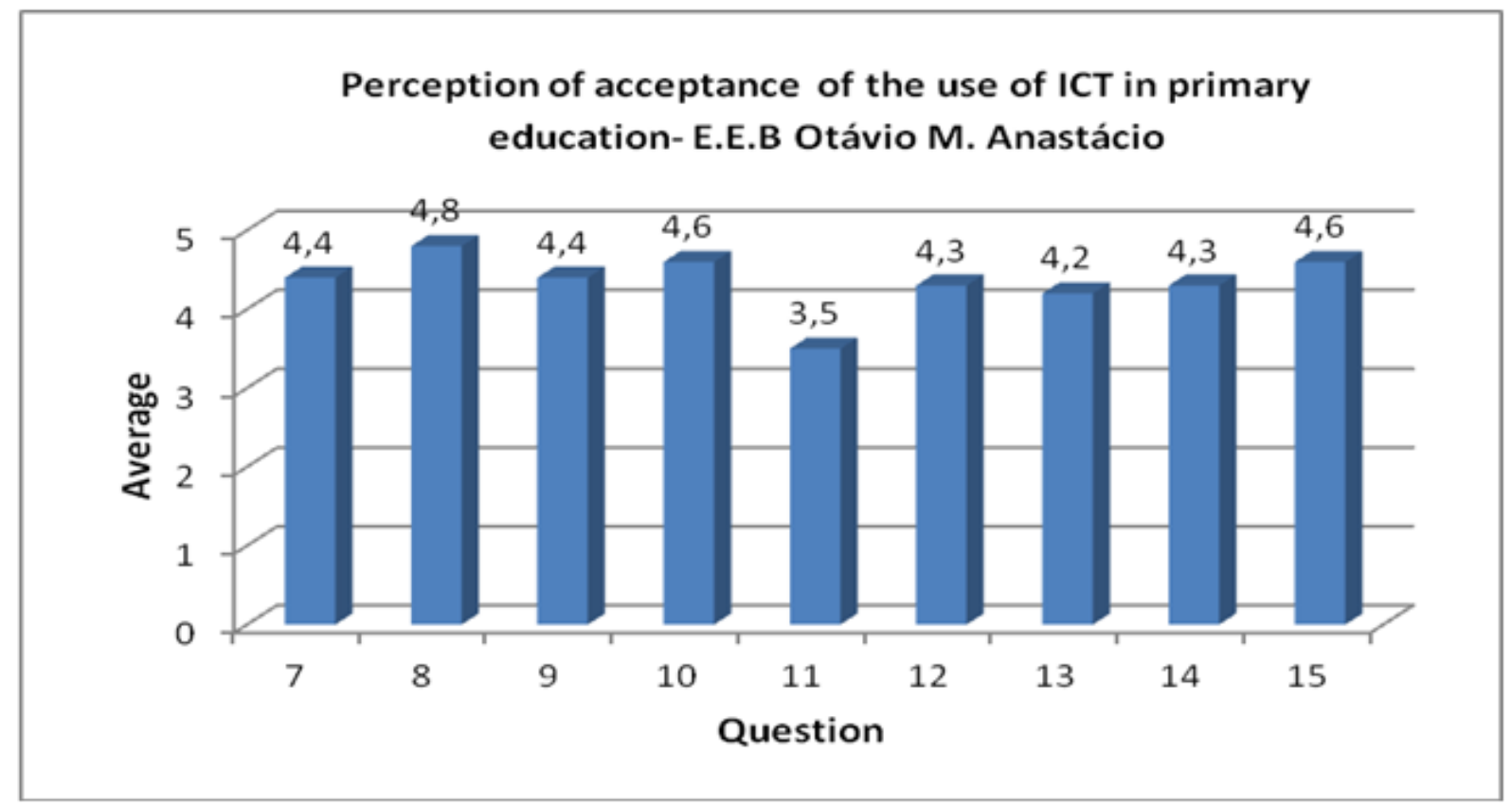

Figure 7. Acceptance of perception of the use of ICT in primary education

It is worth mentioning that at the time of the interview with students, some justifications about the answers surprised us. Including on issues seven (7) and 13 (thirteen), students showed clear dissatisfaction with how to use the computers in the education institution, as stated that is difficult to assess the use of these devices inside the school since they are rarely used, is the precariousness of laboratories, whose few computers often are damaged, or are underused, due to the lack of teacher commitment to draw lessons supported by such technology.

Regarding the teaching perception, in an interview with the project team, the teachers involved in the project reported that the integration of ICT in math classes had a great result. They described the experience as exciting, both for teachers and for students. They said that "Fractions" is a topic of mathematics, considered by teachers and students, one of the issues more complicated to be worked out in the 5th year of teaching critical, therefore, for them the good performance that the students presented in class, during and after the experience was very satisfactory. In the perception of the teachers, students had the highest income in that content when compared to class last year. In addition, they said they were surprised at the ease displayed by children in the use of technology, noting that have a natural disposition for these features.

The teachers also reported difficulties they encounter in the ICT integration process in the classroom, reported that the little technical knowledge hinders the development of activities in the classroom. They said that despite receiving training courses, they needed more experience to develop a greater control of the resources used and failed to resolve any technical problems.

\section{Conclusion}

Technology Integration Actions in Mathematics teaching in Brazilian Basic Education: Stimulating STEM disciplines. Priscila C. Nicolete, Simone M. Sommer, Marta A. da Silva, José P. Schardosim y Juarez B. da Silva.

Página 18 de 22 
It is important to understand that the use of technology can help the teaching practices and motivate process of learning transforming education. It is not technology that changes education, but the good use that is made of it. Use it properly in order to promote good practices to bring out the good educators and future professionals.

In this experience, the teachers made a new horizon possible through a self-assessment, supported by the TPACK framework. Thus, it was possible to get their perception of the integration of technology in their educational practices. Tables and graphics presented shown that it was evident the how teachers questioned both Technological Knowledge (TK), as the Technological Knowledge Content (TCK) and, through this results; they could rethink their practices in the classroom, enhancing teaching through technology integration in their classes. The application of TPACK framework with the teachers succeeded because they themselves described the experience as fascinating while acquiring the little technical knowledge they could, including recognizing the need for more experience to take control of the technological resources available to them today.

A very good index of acceptance was obtained from the students by encouraging them to learn under a new educational paradigm, supported by tablets and smartphones, with suitable software to the level and content to be learned. This approval was evident in some specific questions about the method used in class, especially in the question 8 , which questioned how students felt about the use of tablets in class, and result value 4.8. The same is evident in question 15, when asked about how they would feel if the teacher applied the test in the tablets, and the result achieved index of 4.6 points out of 5 points.

Another factor worth mentioning in the process of technological integration in math classes, is that from the routine of change promoted by the activities described here, both teachers and students have gone to a more critical assessment of reality themselves. Students and teachers began to evaluate what they are getting in the educational field and which could receive, questioning their own ability to learn, and teaching on the resources provided by teachers and managers of schools.

In this new context, all those involved, directly and indirectly recognize the improvements achieved, and one of the immediate results obtained from the school was the commitment of the City Education Department on improving Internet bandwidth in schools. This upgrade on the link was necessary in order to enable the continuation of activities with the students and encourage faculty to develop lessons more dynamic while also keeping the use of the VLE as a way of knowledge sharing.

In this context, which includes the use of accessible technologies, an authentic approach to student reality is possible by creating links from resources that are present in everyday life of the student. Share educational content, without, however, abandoning the interpersonal relationship that allows the growth of everyone involved in the process of teaching and learning. This position enhances cognitive development and promotes necessary features for building new knowledge through communication networks, both teacher/student and student/student, sharing coordinates information or mediated by the teacher. 


\section{Acknowledgments}

We would like to thank FRIDA (Regional Fund for Digital Innovation in Latin America and the Caribbean), CNPq (Brazilian National Council of Scientific and Technological Development) and RNP (Brazilian National Network of Education and Research) for their support and resources to carry out this project.

\section{Note}

I Brazilian education system is divided into basic education and higher education. Basic education corresponds to K12 (Kindergarten-12th grade) the North American education system, covering children and young people of 4 (four) to 17 (seventeen) years of age. Basic education comprises three levels; Children's education (preschool), elementary school (K1 to K9) and high school (K10 to K12). http://www.planalto.gov.br/ccivil_03/leis/19394.htm

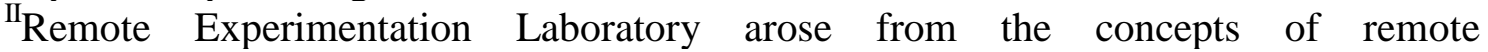
experimentation in 1997 at the Federal University of Santa Catarina (UFSC), which currently has a network of 12 universities (Rexnet) in 5 different countries. Source: http://rexlab.ararangua.ufsc.br/sobre.php

Presentación del artículo: 4 de marzo de 2016

Fecha de aprobación: 26 de abril de 2016 Fecha de publicación: 30 de enero de 2017

Nicolete, P., Bilessimo, S.M.S., Cristiano, A., Simão, J.P., Alves, J.B., y da Silva, J.B. (2017). Technology Integration Actions in Mathematics teaching in Brazilian Basic Education: Stimulating STEM disciplines. RED. Revista de Educación a Distancia, 52. Consultado el (dd/mm/aaaa) en http://www.um.es/ead/red/52

\section{References}

Avison, D. M. (1991). MERISE: A European methodology for developing information systems. European Journal of Information Systems, 1(3), 183-191. doi:10.1057/ejis.1991.33

Batista, S. C. F., Behar, P. A. \& Passerino, L. M. (2010). Recursos Pedagógicos para Dispositivos Móveis: Uma Análise com Foco na Matemática. Revista Novas Tecnologias na Educação (RENOTE), 8(3), 1679-1916.

Barbosa Neto, J. F. \& Fonseca, F. S. (2013). Jogos educativos em dispositivos móveis como auxílio ao ensino da matemática. Revista Novas Tecnologias na Educação (RENOTE), 11(1), 1679-1916.

Butterworth, B. (2002). Mathematics and the Brain. Paper presented at the Opening address to the Mathematical Association, Reading, UK. http://www.mathematicalbrain.com/pdf/MALECTURE.PDF

Technology Integration Actions in Mathematics teaching in Brazilian Basic Education: Stimulating STEM disciplines. Priscila C. Nicolete, Simone M. Sommer, Marta A. da Silva, José P. Schardosim y Juarez B. da Silva. 
Bzuneck, J. A. (2001). A motivação do aluno: aspectos introdutórios. In E. Boruchovitch \& J. A. Bzuneck (Eds.), A motivação do aluno: contribuições da psicologia contemporânea (pp. 9-36). Petrópolis: Editora Vozes.

CAGR. (2013). Sistema de Controle Acadêmico da Graduação. from http://cagr.sistemas.ufsc.br/

Catapan, A. H., \& Fialho, F. A. (1999). Autonomia e sensibilidade na rede: uma proposta metodologica. Paper presented at the Congresso Internacional de Educação a Distância, Rio de Janeiro.

Coperve. (2015). Comissão Permanente do Vestibular.

de Lima, J., Rochadel, W., Silva, A., Simao, J., da Silva, J., \& Alves, J. (2014). Application of remote experiments in basic education through mobile devices. Paper presented at the Global Engineering Education Conference (EDUCON), 2014 IEEE.

Dziabenko, O., \& García-Zubía, J. (2013). IT Innovative Practices in Secondary Schools: Remote Experiments (Vol. 10). España: Universidad de Deusto.

Gallant, D. J. (2010). Science, technology, engineering, and mathematics (STEM) education: McGraw-Hill Education. Retrieved from https://www. mheonline. com/glencoemath/pdf/stem_education.pdf.

Goh, T. T. (2009). Multiplatform E-Learning Systems and Technologies: Mobile Devices for Ubiquitous ICT-Based Education: Mobile Devices for Ubiquitous ICT-Based Education: IGI Global.

Gramani, M. C. N., \& Scrich, C. R. (2013). Influência do desempenho educacional na escolha da profissão. Cadernos de pesquisa, 42(147), 868-883.

Hofmann, J. (2006). Why blended learning hasn't (yet) fulfilled its promises: Answers to those questions that keep you up at night. The handbook of blended learning: Global perspectives, local designs, 27-40.

INEP/MEC. (2013a). Aprendizado dos alunos: Brasil. Retrieved 14 abril, 2015, from http://www.qedu.org.br/brasil/aprendizado

INEP/MEC. (2013b). Censo da Educação Superior no Brasil 2013.

INEP/MEC. (2013c). Censo Escolar Brasileiro 2013. from http://portal.inep.gov.br/basica-censo

Johnson, L., Adams Becker, S., Estrada, V., \& Freeman, A. (2014). NMC Horizon Report: Edição K12 (K-12/2014 ed.). Austin, Texas, Estados Unidos.

Johnson, L., Adams Becker, S., Estrada, V., \& Freeman, A. (2015). NMC Horizon Report: 2015 Higher Education Edition. Austin, Texas.

Koehler, M. J., \& Mishra, P. (2009). What is technological pedagogical content knowledge? Contemporary Issues in Technology and Teacher Education, 9(1), 60-70.

McPherson, S., \& Anid, N. M. (2014). Preparing STEM teachers for K-12 classrooms: Graduate certificate evaluation and innovation. Paper presented at the Integrated STEM Education Conference (ISEC), 2014 IEEE.

Technology Integration Actions in Mathematics teaching in Brazilian Basic Education: Stimulating STEM disciplines. Priscila C. Nicolete, Simone M. Sommer, Marta A. da Silva, José P. Schardosim y Juarez B. da Silva.

Página 21 de 22 
Mishra, P., \& Koehler, M.J. (2006). Technological pedagogical content knowledge: A framework for integrating technology in teacher knowledge. Teachers College Record, 108(6), 1017-1054.

OECD. (2013). Programme for international student assessment (PISA) - Results from PISA 2012.

Pereira, O. R. E. \& Rodrigues, J. J. P. C. (2013). Survey and analysis of current mobile learning applications and technologies. ACM Computing Surveys (CSUR), 46(2), 0360-0300.

Sadovsky, P. (2007). Falta fundamentação didática no ensino da Matemática. Revista Nova Escola-A revista de quem educa (1999), 16-17.

Shulman, L. S. (1986). Those who understand: Knowledge growth in teaching. Educational Researcher, 15(2), 4-14.

Softex. (2013). Inteligência e Observatório. from http://www.softex.br/projetos-para-osetor/observatorio/

Tajra, S. F. (2011). Informática na Educação: novas ferramentas pedagógicas para o professor na atualidade: Érica.

Unesco. (2014). Diretrizes de políticas para a aprendizagem móvel. Brasil.

Unesco. (2015). A educação é imperativa para os direitos humanos, é imperativa para $o$ desenvolvimento, é imperativa para a segurança. Abertura da Semana de Aprendizagem Móvel 2015 na sede da UNESCO. from http://www.unesco.org/new/pt/brasilia/about-this-office/singleview/news/mobile_power_for_girl_power/\#.VO9CmXzF_0w

Welsh, E. T., Wanberg, C. R., Brown, K. G., \& Simmering, M. J. (2003). E-learning: emerging uses, empirical results and future directions. International Journal of Training and Development, 7(4), 245-258. 